\title{
THE EFFECT OF GENRE-BASED APPROACH AND LEARNER AUTONOMY ON THE WRITING COMPETENCE OF THE EIGHTH GRADE STUDENTS OF SMP HARAPAN NUSANTARA
}

\author{
N. M. S. Artini, I K. Seken, I G. Budasi. \\ ${ }^{123}$ English Language Education, Post Graduate Program, Universitas Pendidikan Ganesha, Singaraja \\ e-mail: sriartini46@yahoo.co.id. \\ ketut.seken@pasca.undiksha.ac.id, gede.budasi@pasca.undiksha.ac.id
}

\begin{abstract}
This study aimed at: a) finding out whether or not there is a significant difference in writing competence between the students who were taught by using genre based approach and those who were taught by using a conventional strategy; b) finding out whether or not there is an effect of the interaction between the implementation of genre based approach and learner autonomy on the students writing competence; 3 ) finding out whether or not there is a significant difference in writing competence between the students with high autonomy treated by using genre based approach and those treated by using a conventional strategy; 4) finding out whether or not there is a significant difference in writing competence between the students with how autonomy who were treated by using genre based approach and those treated by using a conventional strategy. The study employed a post test for control group and an experiment group with $2 \times 2$ factorial designs. The population of the study was 196 eighth grade students of SMP Harapan Nusantara in academic year 2015/2016 where 144 of them were selected as the sample of the study through cluster random sampling technique. The data were collected by means of attitude questionnaire and writing competence test and were analyzed by using Two-Way ANOVA and Tukey test. The result of this research showed that: a) there was significant difference in writing competence between the students who are taught by using genre based approach and those who are taught by using a conventional strategy, b) there was significant effect of the interaction between the implementation of genre based approach and learner autonomy on the students' writing competence, c) there was significant difference in writing competence between the students with high autonomy treated by using genre based approach and those treated by using a conventional strategy and d) there was significant difference in writing competence between the students with low autonomy who are treated by using genre based approach and those treated by using a conventional strategy. The implication of this study reveals that a Genre-Based Approach is useful approach for supporting students' development.
\end{abstract}

\section{Keywords: genre-based approach (GBA), learner autonomy, writing competence.}

\section{INTRODUCTION}

Writing is an essential feature of learning a language as it provides a very good means to synthesize the vocabulary, spelling, and sentence patterns. Writing is closely tied to daily communication in the real world and students need to be encouraged to believe that they will never attain full literacy in their second language until they have achieved competence in writing (Patel and Jain 2008, p.125).

In addition, students cannot improve their ability in writing without grammar and structure because the students do not know the pattern of sentence. Therefore, some teachers may still overemphasize the correct grammar, structure and spelling in teaching writing skill. Graham and Porin (2007, p.22) state that excellent instruction in writing not only emphasizes correctness of forms and conventions, but also instills in writers the command of a wide variety of forms, genres, styles, and tones, and the ability to adapt to different contexts and purposes.

However, in the real learning activities in the classroom, the teacher still find the difficulties to determine the most effective way in teaching English writing to senior high school. The majority of the students have difficulty to express their ideas into make a good writing with correct generic structure and grammar. Besides, writing activity needs some processes of thinking. It means that students need to gather their ideas to write a good story or text. Spratt, 
Merry et al (2005, p.27) describe that the nature of writing has a number of stages such as brainstorming, making notes, planning, writing a draft, editing, producing another draft, and proof-reading or editing again.

Furthermore, the students also have problem when they have to develop their thought in a piece of writing because writing is a complex activity in which students need to master some items such as vocabulary, word choice, punctuation, spelling and grammar as well. Those problems lead the students to feel worried in a writing class. In writing, it will be easier for the writer to write a paragraph, if there is a motivation from her mind. So to solve those problems, there is an approach which is helpful to teach writing to the students. It is called Genre Based Approach.

In terms of a classroom implementation, genre-based approach resembles the product approach in that a model text is analyzed on the basis of grammatical and text features. This is followed by guided writing in a joint construction stage before a final, free-writing stage (Badger \& White, 2000). In short, as some authors (Derewianka; 1991; Feez, 1998; Hyland, 2003) suggest, there are two main teaching-learning cycles in standard genre-based writing teaching: Writing with the class and Writing independently. Each of these cycles has associated activities. Writing independently happens when they were able to motivate themselves by finding some alternatives to increase their willingness. When the students have a high motivation, they will be able to make themselves becoming autonomous learners who are able to produce a written text by using their own words.

Several advantages and disadvantages of the three applications of the genre approach have been discussed. Students generally appreciate the models or examples showing specifically what they have to do linguistically. Studying a given genre also provides them with an understanding of why a communication style is the way it is through a reflection of its social context and its purpose. Swales (1990, p.38) pointed out how rhetorical instruction plays as pivotal a role in writing improvement as prior knowledge. In this context, the genre approach is very beneficial because it brings together formal and functional properties of a language in writing instruction, and it acknowledges that there are strong associations between them.

Genre theorists advocate the importance of teaching genre to learners at a young age, as it allows them access into different communities of discourse, as they become aware and understand the convections held by a particular community and realize the purpose of different style of writing for effectively communicating, which prepares them to meet the expectation of their audience. Teaching the structure of different genre therefore allows the writer and the audience, a framework for understanding the text (Fountas and Pinnells, 2012).

In relation among research variables in this study that were Genre-Based Approach and Learner autonomy on the writing competence influenced by personal attitude and interview, analyses of surrounding practices and other techniques researches seek to develop more complete accounts to local writing context. In line of Learner Autonomy can be defined as a personal experiences that the writer brings the writing and the impact of the particular political and institutional context which it on has been defined as "the ability to take charge of one's own learning" (Holec, 1981). By allowing students greater control over their learning they gain responsibility and become decision-makers with the capacity for choosing from among the available resources (Chan, 2003).

Based on the explanation above, this phenomenon in learning activity related to writing is interesting to investigate and this is exactly what the present study is concerned with. The researcher wants to know the effect of genre based approach and learner autonomy on the writing competence of the eight grades students of SMP Harapan Nusantara there was problem still found that indicated unsuccessfulness in improving English writing skill contribute from both teacher and students. It was then thought that is necessary to conduct a research of teaching a language especially for writing skill. The results of this research are expected to have positive implication and provide inputs which can be used in English writing lessons. 


\section{RESEARCH METHOD}

The This research as an experimental study research which aimed in investigating the effect of genre based approach and learner autonomy on writing competence. This research was designed as an experimental group and control group design. The $2 \times 2$ factorial was applied in this study. There were three variables to be studied, the first one is the independent variable; it is the strategies applied in teaching writing, they were Genre Based Approach and conventional writing strategy. The second become a moderator variable is learner autonomy. It is classified the students who have high and low learner autonomy. And the dependent variable was the achievement of writing competence of simple writing of narrative paragraph in English class of eighth grade students of SMP Harapan Nusantra.

The data in the current study presented to reveal the research hypothesis. They were covered in two forms; they are namely descriptive and inferential data. The measurement of the data obtained from post test experimental and control group. They were measured in terms of descriptive statics analysis which covers the measure of central tendency or averages (mean, median, mode) and measure of spread or dispersion (standard deviation, variance and range).

In this research, The data encompasses of the students' writing competency who were taught by Genre-Based Approach, students who were taught by using conventional teaching strategy, high learner autonomy and low learner autonomy, high learner autonomy students who were taught by using genre-based approach, high learner autonomy students who taught by using conventional strategy, low learner autonomy students that taught by using genrebased approach, low learner autonomy students taught by using conventional strategy.

The hypothesis was tested in the present study by analyzing the data inferentially. It was administered statistically by Two-Way ANOVA and Tukey test. All of those testing hypothesis techniques were computed by SPSS for windows. Moreover, according to Sugiono (2007), to prove the data were appropriate to be analyzed, several assumption should be true, such as : (a) the samples are drawn randomly and each sample is independent of other sample, (b) the population under the study have normal distribution, (c) the population from which the sample values are obtained all have the same unknown population variance or the sample must be homogenous.

\section{FINDINGS AND DISCUSSION}

In the first hypothesis testing by Two-Way ANOVA it was found that the $F_{o b}=5.045$ and the significant value was $0.027\left(\mathrm{~F}_{\mathrm{ob}}>\mathrm{sig}\right)$. It showed that the null hypothesis was rejected while the alternative hypothesis was accepted. In the current study for the first hypothesis can be deduced that there is significant difference of writing competence between the students who are taught by using genre based approach and those who are taught by using a conventional strategy.

Two-Way ANOVA for second hypothesis show that $F_{A}=0.247$ and the significant value was 0.621 it can be seen that $F_{A}<$ sig which was meant that the null hypothesis was rejected and the alternative hypothesis was accepted then it can be concluded that there is not significant effect of the interaction between the implementation of genre based approach and learner autonomy on the students' writing competence. The result was also strengthened graphically by the following figure which presented the implementation of Genre-Based Approach interacted with the learner autonomy on the writing. 


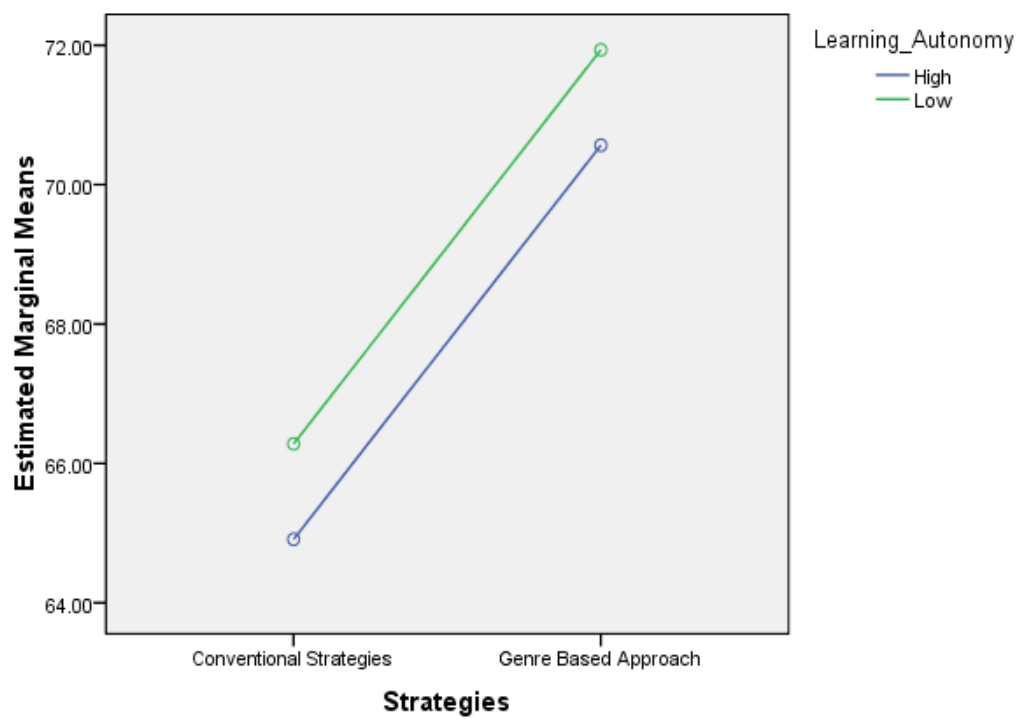

Figure 4.9 The Interaction Between the Implementation of Genre-Based Approach and Learner Autonomy on the Students' Writing Competence.

For the third analysis the value of $Q_{o b}$ was 67.8571 and the value of $Q_{c v}$ was 68.4942 . Thus, the value of $Q o b$ was lower than $Q_{c v}\left(Q_{o b}<Q_{c v}\right)$. So, it can be deduced that the null hypothesis was rejected meanwhile the alternatives hypothesis was accepted or it showed that there is not any significant difference in writing competence between the students with high autonomy treated by using genre based approach and those treated by using a conventional strategy.

Based on the result of fourth hypothesis testing, the analysis above showed that the value of $Q_{o b}$ was 63.3469 and $Q_{c v}$ found was 74.6825. Therefore, the value of $Q_{o b}$ was lower than $Q_{c v}\left(Q_{o b}<Q_{c v}\right.$. So, it can be deduced that the null hypothesis was rejected however, the alternative hypothesis was accepted which was meant that there is a significant difference in writing competence between the students with low autonomy who are treated by using genre based approach and those treated by using a conventional strategy.

\section{CONCLUSION AND SUGGESTIONS}

An experimental research was carried out on the eighth grades students of SMP Harapan Nusantara as the sample. They were divided into two groups: experimental and control group. The experimental group was treated by using a Genre-Based Approach. Meanwhile the control group was treated by using conventional strategy. This experimental research was design by implementing $2 \times 2$ factorial designs which is considered appropriate for experimental research which involves two or more than one independent treatment variables. This research investigated the effect of two independent variable was writing competency. The data were collected through administering writing test measured by analytical scoring rubric which is adopted from Kementrian Pendidikan dan Kebudayaan Direktorat Jenderal Pendidikan Dasar Direktorat Pembinaan Sekolah Menengah Pertama 2013. Kurikulum 2013.(Bahasa Inggris When English Ring a Bell) to gain data on students' writing competency. Learner Autonomy test was collected through kuisioner pembelajaran mandiri dalam belajar bahasa inggris (learner autonomy questionnaire). Moreover, inferential analysis carried out by Two-way ANOVA and Tukey test in order to prove the research hypothesis.

Considering the research findings and discussion presented in the previous chapter, it can be concluded that: 
a) The Result of first hypothesis testing by Two-Way ANOVA show that the $F_{A}=5.045$ and the significant value was $0.026\left(F_{A}>\right.$ sig.). The null hypothesis was rejected while the alternative hypothesis was accepted. In the current study for the first hypothesis of this study can be deduced that there is significant difference of writing competency between students who were taught by using Genre-Based Approach and those who were taught by using conventional writing strategy.

b) The result Two-Way ANOVA for second hypothesis show that $F_{A}=0.247$ and the significant value was 0.621 . It can be seen that $F_{A}<$ sig which was meant that the null hypothesis was rejected and the alternative hypothesis was accepted. It can be concluded that there is not any significant interactional between teaching strategies implemented and learner autonomy on student's writing competency.

c) Based on computation by utilizing Tukey Test in the third hypothesis, it was pointed that the value of the value of $Q_{o b}$ was 67.8571 and the value of $Q_{c v}$ was 68.4942. Thus, the value of $C_{o b}$ was higher than $Q_{c v}\left(Q_{o b}<Q_{c v}\right.$. So, it can be deduced that the null hypothesis was rejected meanwhile the alternatives hypothesis was accepted or in other word it can be said that there is not any significant difference in writing competence between the students with high autonomy treated by using genre based approach and those treated by using a conventional strategy.

d) Based on the result of hypothesis testing, the analysis above showed that the value of $Q_{o b}$ was 63.3469 and $Q_{c v}$ found was 74.6825. Therefore, the value of $Q_{o b} w a s$ lower than $Q_{c v}\left(Q_{o b}<Q_{c v}\right)$ So, it can be deduced that the null hypothesis was rejected however, the alternative hypothesis was accepted it was found that there was significant effect between Genre-Based Approach and Learner Autonomy toward writing competence. Furthermore, the implementation of Genre-Based Approach and Conventional Writing Strategy obtained different effect on student's writing competency where students who were taught by using Genre-Based Approach obtained higher means score rather that those who were taught by using conventional writing strategy.

Based on this research, it has been discussed that the result of the study showed that student's writing competence was influenced by the implementing of Genre-Based Approach and Learner Autonomy on the Writing Competence. On the other words, both Genre-Based Approach and Learner Autonomy toward writing affected student's success in learning especially in writing. The students who were taught by using Genre-Based Approach was better than those who were not taught by using Genre-Based Approach on students' writing competence. Moreover, the students writing competence of high learner autonomy taught by using teaching strategies implemented was better than those low learner autonomy toward writing.

The result of this study also reveals that a Genre-Based Approach is useful approach for supporting student's development. The students under study were able to develop their writing skill as a result of this approach. They could be able to understand and apply the knowledge they learnt to improve their writing. By implementing Genre-Based Approach, students could recognize the generic structure and particular language features of a genre especially narrative paragraph. Students could draw on this knowledge in helping them contact and improve their own text as prove in this study.

\section{ACKNOWLEGMENT}

My principal supervisor Prof. Dr. I Ketut Seken, MA and my second supervisor Dr. I Gede Budasi, M.Ed, Dip, App. Lin., whose patience, expertise, encouragement, and gentle guidance have kept me focused on the task at hand.

The Rector of the Ganesha University of Education for the moral supports and facilities, prior to and during the completion of my study in the university.

The Director of Post Graduated Study Program, Ganesha University of Education for his support, motivation, and encouragement so that I could keep going and finalize this thesis.

The Headmaster and English teacher of SMP Harapan Nusantara for their permission and cooperation the time the research during this thesis was conducted. 
The whole friends who cannot possibly be mentioned one by one. Their friendship, support, motivation, and encouragement have been invaluable and helped support me through of this academic journey.

\section{REFERENCES}

Badger, R., \& White, G. (2000).A process genre approach to teaching writing.ELT Journal, 54 (2), 153-160.

Bhatia, V.K. (2002). Applied Genre Analysis: Analytical Analysis and Pedagogical Procedures in Genre in the classroom: Multiple Perspective, ed. Johns and Ann M. New York and London : Routledge.

Brannan, B. (2009). A Writer's Workshop: Crafting Sentences, Building Paragraphs. Kansas: Higher Education.

Brindley, S. (2005). Teaching English. New York: Routledge

Broughton, G., Brumfit, C., Flavell, R., Hill.P. \&Pincas, A. (2003). Teaching English as a Foreign Language. New York: Routledge.

Brown, H. D. (2007). Principle of Language Learning and Teaching ( $5^{\text {th }}$ ed.). New York: Pearson Education.

Byram, M. (2004). Genre and genre-based teaching. The Routledge Encyclopedia of Language Teaching and Learning (pp. 234-237). London: Routledge.

Chan, V. (2003). Autonomous Language Learning: the teachers' perspectives. Teaching In Higher Education, 8(1).33-54..

Derewianka, B. (1991). Exploring how texts work. Rozelle, NSW: PETA.

Derewianka, B. (1993). Variation on a theme: Working with whole texts in LOTE. Wollongong: Faculty of Education, University of Wollongong.

Fountas, C.I. and Pinnell G.S. (2012).Genre Study : Teaching with Fiction and Notification Book. Heinemann : Portsmouth, $\mathrm{NH}$.

Fulcher, G. \& Davidson, F. (2007).Language Testing and Assessment. New York: Routledge.

Graham, S. \&Porin, D. (2007). Writing Next: Effective Strategies to Improve Writing of Adolescents in Middle and High Schools - A Report to Carnegie Corporation of New York. Washington DC: Alliance for Excellent.

Halliday, M.A.K. (2009). Context of Culture and Situastion. In J.J Webster (ed), The Essential Halliday (p.55-84). London: Continumm.

Harmer, J. (2004). How to Teach Writing. England: Longman.

Hayland, Ken. 2004. Second Language Writing. New York : Cambridge University Press.

Holec, H. (1981). Autonomy and Foreign Language Learning. Oxford: Pergamon.

Hyland, Ken.(2003). Second Language Writing. New York : Cambridge University Press.

Johnson, D. W. \& Johnson, R. T. Meaningful Assessment. (2002). Boston: Pearson Education Company.

Kagan, S. (1994).Cooperative learning. California: Kagan Cooperative Learning.

Kane, T.S. (2000). The Oxford: Essential Guide to Writing. New York: The Berkley Publishing Group.

Lin, N. (2003). English in Singapore: An insider's perspective of syllabus renewal through a genre-based approach. RELC Journal, 34(2), 223-245. 
Little, D. (2007). Reconstructing Learner and Teacher Autonomy in Language Education, in Barfield, A. and S. Brown, S. (Eds) Reconstructing Autonomy in Language Education: Inquiry and Innovation. pp 1-13. Basingstoke: Palgrave Macmillan.

Littlewood.W. (1996).Autonomy.An Autonomy and a Framework System 24 (4). 427.435.

Macken-Horarik, M. (2001). 'Something to shoot for: a systemic functional approach to teaching genre in secondary school science' in A. M. Johns (ed.) Genre in the Classroom: Multiple Perspectives. London: Lawrence Erlbaum Associates.

Martin, J. R. (1992). English Text. Amsterdam: Benjamins.

Nunnan, D (1999). Second Language Teaching and Learning.Boston :Heinle\&Heinle.

Oshima, A and Hogue, A. 2007. Introduction to Writing Academic English.Third Edition. New York : Pearson Education.

Paltridge, B. (2001). Genre and the language learning classroom. Ann Arbor, MI: University of Michigan Press.

Paris, S. G., \& Winograd, P. (1990). How metacognition can promote academic learning and instruction. In B. F. Jones \& L. Idol (Eds.), Dimensions of thinking and cognitive instruction. Hillsdale, $\mathrm{NJ}$ : Earlbaum.

Patel, M.F \& Jain, P.M. (2008).English Language Teaching. Jaipur: Sunrise Pubishers\& Distributors.

Raimes, A and Jerskey, M. 2011. Keys for Writers. Sixth Edition.USA : Wadsworth Cengage Learning.

Richards, J. C. and Schmidt, R. (2002).Dictionary of Language Teaching and Applied Linguistics Third Edition. Edinburgh: Longman.

Rumisek, L.A. \& Zemach, D.E. (2005).Academic Writing from Paragraph to Essay. Spain: Macmillan Publishers

Savage, A. \& Shafiei, M. (2007).Effective Academic Writing1, The Paragraph. New York: Oxford University Press

Scharle, A., \& Szabo, A. (2000). Learner autonomy: a guide to developing learner responsibility.Cambridge: Cambridge University Press.

Smith RC. 'Pedagogy for autonomy as (becoming-)appropriate methodology'. In: Palfreyman $D$, Smith RC, editors. 2003 http://eltj.oxfordjournals.org/content/62/4/395.full

Swales, J. M. (1990). Genre analysis: English in academic and research settings. Cambridge, UK: Cambridge University Press.

Slavin, R.E. (1995). Cooperative learning: Theory, research, and practice. (2nd edition).

Spratt, Marry et al. (2005). The TKT Course. Cambridge: Cambridge University Press.

Sugiyono.2005. Statiska untuk penelitian. Bandung: Alfabeta. 